\title{
Iranian Elites under the Timurids
}

\author{
Beatrice F. Manz
}

The pre-modern history of the Islamic Middle East is seen largely in two contexts: the court and the city. This is what our sources will illuminate for us. The cities we learn about are the largest ones - the dynastic and regional capitals. The elites described are the ones who inhabit these two major venues; the dynasty and standing army, personnel of the court and chancellery (dīwān), and city notables, especially the religious classes. The bureaucrats might influence administrative policy, while the power of the 'ulama' lay in their social influence and their ability to act as intermediaries between state and population. Seeking the link between government and society, naturally then we have looked to the relationship between court and city.

In the territory of Iran, with which I am concerned here, pre-Islamic society has been presented very differently. Regions were dominated by landed elites: on one level great lords and below them the famous gentry class, the dihqāns, central to both Sassanian administration and military might. There has been a general consensus among historians that this system changed gradually after the Arab conquest. At least at the lower level, the Iranian landowning elites remained important through the Samanid dynasty (819-1005 AD). After that they fade from view in the medieval historical sources, especially from the Seljukid period (1038-1194) when Turkic nomads from the steppe became rulers over much of the Middle East. From this time on we read about Iranian bureaucrats and 'ulama', but the military has usually been understood to belong primarily to the Turks, whether slave soldiers or free nomad troops. In general, modern historical writing has mirrored this picture. ${ }^{1}$ The question we need to ask is whether the regional Iranian elite actually lost direct political and military importance, or simply became less visible in the written sources. I am using the term "Iranian" here in the sense in which medieval historians used the term "tajik": meaning the non-turkic, primarily settled, population of Iran and Central Asia, in contrast to the Turks, identified as originally nomadic peoples of the steppe.

1 See for example: Garthwaite, The Persians, pp. 107, 124-125; Amitai, "Armies and their economic basis in Iran", pp. 539-544. 
The position of the Iranian elite, particularly in relation to military activity, has begun to receive attention over the last decade and a half. For the larger cities, the importance of both the urban population and the city notables in military defense has been clearly demonstrated. Several scholars writing on the middle periods of Islamic history (c. 1138-1500) have shown that the urban populations remained active in city defense under the leadership of city officials. It is harder to illuminate the position of local elites in smaller cities and in more rural areas, which of course made up the majority of territory and population. Even for such significant cities as Kashan, Qazwin or Damghan, we have almost no information. The sources give us just enough evidence to show that a significant number of elite Iranians continued to engage in military activity, but we have to strain to see them. The relationship of elite status to land ownership also remains uncertain, though the fact that Iranian elites continued to hold regional power - as I shall show - presupposes an income from

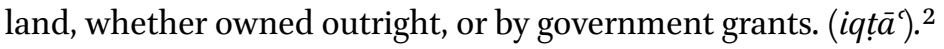

Despite the paucity of evidence, I want to pose several questions about the nature of the Iranian elite, looking at both the civilian and the military sphere. I will engage in speculation beyond what the sources fully support and suggest that we consider the likelihood that Iranian landed elites remained widespread, active and multifaceted, even in periods of strong central rule. I believe this is true not only of the city populations, which have already been studied, but of the elites of towns and rural regions as well. Although some of my conclusions must remain tentative, it seems to me that we can no longer accept uncritically the picture our sources suggest, of a politically weak elite, active primarily in civilian affairs. Since we know that our sources distort our picture, we need to work actively to correct the image they present.

Before we can attempt to understand the Iranian elites, we must face the extent of our ignorance. We are hampered in our search for understanding not only by the lack of sources, but also by the programmatic nature of the information our texts give us. Since we have very few original documents for the pre-modern period, we are dependent on sources in which information has been collected and organized for a specific purpose. There are several types of systematic distortion common to all the works at our disposal.

2 On this subject see Paul, Lokale und imperiale Herrschaft im Iran des 12. Jahrhunderts, pp. 119, 146. 
One problem comes from the genres into which historical writing was divided. The political narrative is given in historical chronicles which focus on ruler and army; these are accounts of campaigns, disposition of territory, dynastic and court events. Bureaucrats appear here occasionally when appointed, dismissed or associated with a particular event. The city notables and religious classes appear more rarely, usually in very short mentions. Our major source of information on the Iranian elites outside army and court is the biographical literature, which provides notices on the lives of ulama, poets, bureaucrats, and Sufis. Here the ruler or a prince may appear, but political events, campaigns and the Turco-Mongolian military play a small part. ${ }^{3}$ Thus the organization of information in the sources emphasizes separation between the Iranian and Turco-Mongolian populations, and between civilian and military spheres.

Another systematic distortion in our sources, particularly from the Seljukid period on, is the tendency to suppress coverage of Iranian military activity because the military was considered the sphere of the dynasty and its standing armies, with the occasional assistance of nomadic populations. War for religious purposes was one exception to this; otherwise histories regularly downplayed the military role of city or rural populations. This is particularly true of the histories written for the central court, on which we depend for much of our information on military activity. ${ }^{4}$ Even where regional armies are mentioned

3 One can take as examples the famous biographical collection by the poet and vizier Navầ', Majālis al-nafä̀is (Persian translations from the Chaghatay original: The Latāifnāma of Fakhrī Harātī, and a translation by Muḥammad b. Mubārak Qazwīn̄i), and 'Abd al-Raḥmān Jāmī's work on the lives of well-known Sufis, Nafahât al-uns. An exception to the rule is the biographical collection of Dawlatshāh Samarqandī on the lives of poets; the unusual focus here is due probably to the fact that the author came from a military family, and himself held military posts in his early years (see Manz, Power, Politics and Religion, p. 62). Biographies of bureaucrats, who worked closely with both rulers and commanders, contain more information on politics and military campaigns, but little on the part that viziers played in them. The two collections from the Timurid period are: Khwāndamīr, Dastūr, and 'Uqaylī, Āthār al-wuzarā'.

4 For the earlier period see Durand-Guédy, "Iranians at War under Turkish Domination", pp. 588-590, 595. For the Timurid period, we have two histories of the reign of Temür, the Zafarnāma of Nizāàm al-Dīn Shāmī written towards the end of Temür's life, and the Zafarnāma of Sharaf al-Dīn 'Alī Yazdī, written in Shiraz during Shāhrukh's reign, and based on Shāmī's history; both are focused strongly on Temür himself. (Shāmī, Zafarnāma; Yazdī, Zafarnāma). For the later periods there are four major histories, all written by scholars or bureaucrats close to the court and under court patronage. The history of Hāfiż-i Abrū, written for Shāhrukh, incorporates and expands the Zafarnāma of Niẓām al-Dīn Shāmī, continuing the story to the time of his death in 833/1430. This history in turn became the foundation of the Mațla' al-Sa'dayn wa majma' al-bahrrayn of 'Abd al-Razzāq Samarqandī, who served both 
and where it is clear that they consist of Iranian troops, histories rarely report Iranian performance in battle or the names of regional commanders. Local military powers appear somewhat more clearly during periods of disorder, when no powerful state dominated the region and the limelight. At such times leading families took advantage of the confusion to establish control over their own regions and became significant actors in a general struggle for power.

A few areas in Iran have local historiographical traditions producing historians with a strong attachment to the region, writing both specifically local histories and more general chronicles which contain valuable details on events in their own areas. Regional elites appear more clearly in such histories, particularly those about areas distant from the center of power, such as the Caspian regions and the desert areas of eastern Iran like Farah and Sistan, both of which were often under their own kings. In the histories of these places we can see something of the activities of a second tier of actors, the lords and commanders under local kings. Histories of the regions close to provincial or imperial capitals, such as the district of Yazd or Khurasan, provide less detailed information. However, though the difference is subtle, the role of local actors does emerge more clearly in these works than in most dynastic histories. Thus for instance, describing an uprising in Yazd in 798/1395-6, dynastic histories attribute the action to an outside amir of Turco-Mongolian descent, while local histories reveal that this amir was invited into the city by actors within it, and that not only Turco-Mongolian but also local officials were attacked. ${ }^{5}$ Writers describing events involving their own cities often provide valuable details on local actors ignored by the more centrally located historians. Such histories have helped scholars gain insight into the active military role played by the urban population and notables in city defense. Here it is clear that religious personnel played an important part, and the effort was most often led by the city's chief $q \bar{a} d \bar{d}$. The notables and population might act in conjunction with Turco-Mongolian officials or separately. Many fighters were artisans but both they and their leaders clearly had some military experience, particularly in archery. ${ }^{6}$

Shāhrukh and his successor Sulțān Abū Sa'īd, and completed his history in 875/1470. Samarqandī was trained in the religious sciences, and gives somewhat more coverage to chancellery and religious affairs. The last two historians, Muhammad b. Khwāndshāh b. Maḥmūd, known as Mīrkwhānd (d. 903/1498) and his grandson Khwāndamīr (d. 1530 or 1542), were also trained in religious sciences; both were active in the court of the last Timurid ruler, Sulțān Husayn-i Bayqara. Both likewise incorporated the work of earlier historians into their own. (See Manz, Power, Politics and Religion, pp. 51-61, for summary and references.).

5 See Manz, "Local Histories of Southern Iran"; for the Yazd uprising, pp. 272-275.

6 Durand-Guédy, "Iranians at War"; Paul, "Wehrhafte Städter", pp. 182-19o; Manz, "Nomad and Settled", pp. 428, 434-446. For an earlier period, this subject was taken up by Claude Cahen many years ago in his monograph Mouvements populaires et autonomisme urbain. 
When we turn to the activity of elites in the civilian sphere, most notably within the religious professions, Sufi orders, and the dīwann, our sources are somewhat fuller. The biographical literature in Persian is far less detailed than it is in Arabic, especially for the middle periods, with which we are concerned here. While Arabic biographical dictionaries often provide quite long biographies covering an entire career, most Persian biographies, whether in collections or within narrative histories, rarely exceed a few paragraphs. Nonetheless we do have sketches of many scholars and some bureaucrats; there is also a rich fund of biographies of Sufi shaykhs, which are longer-if not more systematic - than those of other people. Grave visitation manuals provide some additional material. Such sources usually stress intellectual and family filiations, and have been widely used for social history. However, it is important to recognize that these texts, though they enlighten, also distort. The problem here is that biographical collections are usually concerned with individual professions or with individuals as they related to their occupation. The filiations they report are usually those that remain within the profession; we know of the sons who follow their fathers, and of disciples who marry into the family. But are those mentioned the only sons and the only marriageable daughters? If we do not hear about others, it might not be due to lack of success, but to their choice of a career path that does not fit into the narrative. The picture presented is not false, but we should recognize that it is also not complete and that the omissions are probably not random.

One further small fund of information is available which can help us to counteract the limitations of the master narrative, and this is the autobiographical material included by some historians in their chronicles. The narrative is almost never complete, and consists usually of brief mentions of specific occasions and relationships. Nonetheless it sometimes breaks outside of the conventions governing the central texts, to include information which would elsewhere be considered irrelevant. Here I would like to examine two examples of what can be learned. The first text I will examine is an historical compendium known as Mujmal-i Fașīhī, written by a mid-level Khurasanian bureaucrat, Aḥmad Fașịh Khwāfì (d. after 1441/2). The Mujmal is an abbreviated chronicle starting with Adam and going up to the author's time, giving for each year a list of major events, with births and deaths of important people. Fașịh Khwāfi was a native of Khurasan with strong local connections, which are evident in the history. We are able to trace something of his ancestry, career path, and acquaintance. The Mujmal provides us a good illustration of how an elite regional family developed and how one individual placed himself within it.

As Fașīh Khwāfì reaches his own time he begins to include the members of his own extended family, and indeed the births of his own sons, despite his rather modest standing. Although Fașị and those of his close relatives he 
mentions did not have distinguished careers in the Timurid dīwān he did come from prominent ancestors on both sides. Fașị gives the death notice of his father in the year 1393/1394, tracing his ancestry back to Abū Imāma Ṣadī, companion of the Prophet and hadīth transmitter. However, Fașị offers no information about his father's life besides his burial place, and I have found no other member of his family on this side elsewhere in the history. ${ }^{7}$ The family that was important locally, and which probably provided Fașị with his professional contacts, was that of his mother. This family also probably provided him with the nisba Khwāfi. The family claimed descent from the famous Ghaznavid vizier, Abū Nașr Mishkān, a highly suitable ancestor for a dīwān family, but more immediately from a warlord of Khwāf, Majd al-Dīn Muhammad, an ambitious and rebellious servitor of the Kartid kings (1245-1389) who ruled part of Khurasan from Herat. After Majd al-Dīn's defeat by the Kartids some of his progeny apparently continued in the dynasty's service. Aside from parents and sons, Fașị mentions only two people related to him; two second cousins from his mother's branch, who appear to have served in the Herat diwwann during Temür's life. ${ }^{8}$ Fașị̣̂'s history thus lets us see two things which might not appear in a general history or standard biography. The first is the choice of connections an ambitious man might use; Fașị Khwāfì clearly profited from the prominence and professional connections of his mother's family rather than that of his father. The second and related revelation is the selectivity of the connections mentioned - the only contemporary relatives who appear are his second cousins, who were in a similar career path and probably somewhat more advanced than he.

I will conclude this section with an illustration of the influence that genre and the circumstances of writing have on the information offered about a given person in historical texts. We have a good example of the differing kinds of information offered by works of varying types in the portraits they give of one particular official who combined religious, bureaucratic and military activity throughout a distinguished career. Khwāja Ghiyāth al-Dīn Muḥammad Rāzì, called Ḥāfiz Rāzī (d. April/May 1422), was the main vizier and șadr (supervisor of religious offices) in Fars, and a prominent military commander for the Timurid prince Iskandar b. 'Umar Shaykh (d. 1415), who was the semiindependent governor of Fars early in the reign of Shāhrukh (r. 1409-1447). As an important provincial figure, Hâafiz Rāzī is briefly mentioned in several

7 Fașịh, Mujmal, III, pp. 137-138.

8 Fașịh, Mujmal, III, genealogy: pp. 110, 214, 251. We know that Fașịh's relatives were dismissed by Sayyid Fakhr al-Dīn Muhammad, sent by Temür to shake up the Herat dīwān and administration (p. 150). 
sources: he is listed as vizier for Iskandar in the dynastic genealogy, the Mu'izz al-ansāb; he is briefly noted in the Tadhkirat al-shu'arā' of Dawlatshāh Samarqandì (d. after 1487), which chronicles the lives both of poets and of the dynasty; and his death and burial are mentioned in the Mujmal-i Fașịhi. ${ }^{9}{ }^{9}$ Hāfiz Rāzī also appears in a Sufi source: the biography of Shāh Ni'mat Allāh Walī Kirmānī, active in the early Timurid period. Here he appears doing honor to Shāh Ni'mat Allāh at a public audience in Shiraz, and is identified as șadr and as a student of the famous scholar Sayyid 'Alī Jurjānī. ${ }^{10}$ In each source he appears as he fits into the specific narrative being presented.

Hâafiz Rāzì was a native of Yazd, a city which produced a spate of historical writing during the Timurid period. In the local histories we learn considerably more about his activities. Three of the histories written in Yazd focus on the history of the city itself: the Tärīkh-i Yazd and Tärīkh-i jadīd-i Yazd from the Timurid period, and the somewhat later Jāmici $i$ mufidì. The first two histories are concerned primarily with the built environment and where Haâfiz Rāzì is mentioned it is usually in connection with buildings, though the fuller Tärïkh-i jadìd also identifies him as vizier and gives several anecdotes about his life centered on his relations with the dynasty. ${ }^{11}$ The Jāmici $i$ mufìdı̄ includes Haāfiz Rāzī in its biographies of notable figures; here there is discussion of his learning, his service as vizier under Iskandar, and later his entertainment of Shāhrukh and his involvement in producing a cover which Shāhrukh attempted to donate to the Ka ${ }^{c}$ ba $^{12}$ In none of the histories focusing on the city of Yazd is there any mention of Haāfiz Rāzì's military activity. However, the historian Jafarī, who wrote the Tärīkh-i Yazd, also produced a general history up to his time, and here Hâấ Rāzī is listed as one of several commanders that the prince Iskandar sent on an expedition against Qum. ${ }^{13}$ Much the fullest account of Ḥāfiz Rāzī, and the only extended discussion of his military role, is found in one history, the Jämic al-tawārïkh-i hasanī, written in 1451-1453 by Hasan b. Shihāb Yazdī. Here Hâfiz Rāzīs military position is given considerable prominence. This unusual emphasis is undoubtedly due to the fact that the author served in the army under Ḥāfiz Rāzī, as commander of ten men. He states that Ḥāfiz Rāzī was tovachi (troop inspector, usually also in charge of conscription) of a tümen - that is to say a troop theoretically numbering 10,000, the largest size of regiment in the army. Haâfiz Rāzì also commanded a special regiment

Mu'izz al-ansāb, f. 108a; Dawlatshāh, Tadhkirat, p. 375 (mentioned as vizier for a different prince); Fașīh, Mujmal, III, p. 251.

10 Aubin, Matériaux pour la biographie de Shah Ni'matullah Wali Kermani pp. 86-87, 180.

11 Ja'farī, Tärīkh-i Yazd, p. 121; Kātib, Tärïkh-i jadīd-i Yazd, pp. 147-149, 207.

12 Bāfqī,Jāmici $i$ mufìdi, III, pp. 155-157.

13 Ja'farī, Tärïkh-i kabìr, f. зоза. 
known as the Qushun-i Jānbāz, and according to Hasanī accompanied the prince Iskandar on all important expeditions. ${ }^{14}$ When we take all these histories together, we can see the progression in information and the way in which different roles are separated; in sources written outside the province, Hâfiz Rāzī receives an occasional mention as vizier; in provincial biographical and urban literature he appears in his civilian role, while the locally written history describes local campaigns in sufficient detail to list him on one campaign. For an understanding of his military role we depend on the historical chance of a particular author who served under him.

While the central subject of this chapter is the elite of the Timurid period, the role of Iranians under the Timurids was not an exception but the continuation of an earlier pattern predating the Mongol invasion and lasting through it. I will therefore briefly review what we know about the military activities of the Iranian elites in earlier Islamic periods, concentrating on those outside the major cities. Despite our problematical sources it is possible to trace the evolution of the Iranian elite up to the Timurids, at least in its broadest outlines. Looking at the history of Iran from the Arab conquest we can see first the continuation of the dihqāns as a landed elite with a military tradition lasting through the Samanid dynasty, and after them an elite of probably mixed provenance, who still held regional power at a local level and led retinues of soldiers. In several studies, Jürgen Paul has traced the activities of regional Iranian elites through several centuries, showing them active particularly in matters of local administration, but also sometimes in the military. ${ }^{15}$ Recent studies on Iran under the Seljukids likewise show families wielding regional military power; the picture is clearest for the city but at least some of the militias mentioned were clearly recruited from the countryside and used outside the city. ${ }^{16}$ In the later Seljukid period the great notable families of Isfahan were able to keep out Seljukid claimants for power, and at the end of the Seljukid period

\footnotetext{
14 Yazdī, Hasanī, pp. 14, 24; Manz, Power, Politics and Religion, p. 149.

15 Jürgen Paul provides an excellent detailed discussion of local Iranian elites in the twelfth century in his book, Lokale und imperiale Herrschaft im Iran des 12. Jahrhunderts, cited above. Several earlier works of his also provide information on elites before the Timurid period: The state and the military: the Samanid case; "Where did the dihqāns go?"; Herrscher, Gemeinwesen, Vermittler, pp. 93-146.

16 Durand-Guédy, Iranian Elites, pp. 58, 117, 174-176, 218.
} 
much of actual power within the Isfahan region was in the hands of local notable families, allying with outside powers for their own advantage. ${ }^{17}$

A particularly active period for Iranian military elites is the one just preceding the Mongol invasion, when Seljukid power had faded and the Khwarazmshāhs (c. 1077-1231), centered in the Aral Sea region, the caliph in Baghdad, and the Iranian Ghurid dynasty (c. 1100-1215) of the Herat region had exhausted themselves in their struggle over the Iranian plateau. The presence of competing claims in the area led to a proliferation of smaller regional powers which together controlled a large portion of the Iranian plateau. We find local dynasties and their servitors in Mazandaran, sometimes stretching to Damghan and Simnan on the northern corridor, in Quhistan, Ghuristanthe area around Bamyan, stretching to Herat-, in Sistan, Hormuz, Fars, and Luristan. These small states were frequently at war, using local armies under subordinate commanders, who sometimes switched allegiance to other dynasties. There was also considerable internal dissention caused by rivals for power within the dynasty and commanders eager for adventure. ${ }^{18}$ Within the Khwarazmshāh's domains likewise, the importance of regional lords was recognized by the historian Nasawī (d. 1249-50) and the geographer Yãqūt (d. 1229), who attributed some of the weakness of the realm before the Mongol onslaught to the Khwarazmshāh's execution of members of several powerful families, including the governors of major cities. ${ }^{19}$

Two histories from the early Mongol period give us an unusually detailed description of politics in eastern Iran on the eve of the Mongol invasion. ${ }^{20}$ Among other things they allow us to follow the activities of regional military elites quite clearly in Ghuristan, a mountainous region in which prominent families centered themselves in fortresses and competed for power over neighboring territories. Here for several decades before and after the Mongol conquest a number of powerful families vied for control over Herat and its region, some remaining loyal to the declining Ghurid dynasty, and others eager to ally with outside powers to gain their ends. In the end one of these families - the Kartids-surrendered their fortress to join the Mongols and founded a new polity which lasted to the Timurid conquest. Until the end of the Ilkhanate the Kartids remained loyal vassals to the Ilkhans, then becoming a largely independent regional power until their defeat by Temür in $784^{-5} / 1383$. We find several

17 Durand-Guédy, Iranian Elites, pp. 172-173, 257-258, 281-292.

18 Manz, "Nomads and Regional Armies", pp. 6-11.

19 Paul, "L'invasion mongole comme 'révélateur' de la societé iranienne”, pp. 45-46.

20 Jūzjānī, Ṭabaqāt, trans. Raverty; Jūzjānī, Ṭabaqāt, ed. Ḥabībī; Nasawī, Sìrat as-Sulțān Dzhaläl ad-Dìn Mankburny. 
Ghurid commanders incorporated into the armies of the Khwarazmshāhs, and others following their own rulers into India where the Ghurids founded the Delhi Sultanate. ${ }^{21}$ Most remained and served the Kartid dynasty, under which the Ghurid amirs wielded considerable political power, especially at times of weak rule. ${ }^{22}$ The Kartid army was strong enough to inflict some defeats on the nomad armies of the Ulus Chaghatay, a tribal confederation based in Transoxiana, until Temür's rise to power changed the equation. ${ }^{23}$

Mongol conquest and rule did not destroy the power of local Iranian elites; in some places indeed they may well have profited. In Fars, ruled by the Turkmen Salghurid dynasty (1148-1270) under Mongol oversight, regional elites became agents of Salghurids and Mongols, serving as governors or local lords and administering many of the smaller cities and villages and referred to collectively as hukkām and mulük. Despite the increase in crown lands Iranian notables, including shaykhs and bureaucrats, were able to build up large landed estates. Viziers, local notables, and the hukkām and mulük all took an active part in politics and were not slow to enrich themselves both at the expense of the population and with bribes extracted from Mongol amirs. ${ }^{24}$

At the end of the Ilkhanid dynasty both Turco-Mongolian amirs and Iranian commanders hastened to take advantage; of the six substantial successor polities which emerged within the struggle, four were ruled by Iranians. The Kartid dynasty of Herat has already been mentioned. In Fars two dynasties founded by Iranian servitors of the Ilkhans - the Injuids (c. 1325-53) and the Muzaffarids (1314-93) - competed for power. They were constantly at war, both against each other and within their own realms. It was not only within the vassal polities that local lords kept their power under the Mongols. Even in western Khurasan, which was a center for Mongol power during the Ilkhanate, regional elites were among the political powers active after the Ilkhans. These elitesreligious and secular-provided the impetus and most of the leadership for the Sarbadar movement, which controlled varying amounts of territory in the region from 1336 to 1381 . The movement began with a rebellion by 'Abd alRazzāq, member of a powerful family of Bashtin, near Sabzawar. His father is described as an amir, suggesting a military career. Beginning with his own retainers, allies and relatives, he took Sabzawar, and from this time to the end of the dynasty we find the Sabzawari aristocracy as part of the leadership, not

21 Manz, "Nomads and Regional Armies", pp. 17-20; Jackson, The Delhi Sultanate, pp. 17-18, 41-42.

22 Potter, "The Kart Dynasty of Herat", pp. 68, 132-134.

23 Aubin, "Le Khanat de Čagatai et le Khorasan", pp. 23, 29, 35.

24 Aigle, Le Fārs sous la domination mongole, pp. 90-94, 128-129, 133, 138, 152-153. 
infrequently in competition with the elite of Bashtin. Several different families were active here, sometimes in alliance and sometimes in competition, and when the movement was powerful, other regional powers voluntarily submitted. ${ }^{25}$ Despite frequent wars with its neighbors, the dynasty survived up to the time of Temür.

Alongside these powers were countless smaller realms kept or carved out in the post-Ilkhanid confusion. The historian Faryūmadī, describing the disorder after the Ilkhan Abū Sa'id's death in 1335, gives a list of local uprisings and seizures. Some of the actors appear to have been Turco-Mongolian amirs, but many were Iranians. Thus, for example, power in the region of Kashan was taken for a while by Sayyid Latīf-Allāh Kāshī, a local sayyid and naqīb; Khwāja Tāj al-Dīn 'Alī Aṣil controlled Qum for a time; Amīr Jalāl Khurāsānī held Qal'a-i Āwaral; Amīr Mas'ūd Wazwāī held the fortress of Gīw until killed by his son. ${ }^{26}$

As we can see from the brief summary above, it is clear that Iranian elites continued to be part of the political and military landscape after the advent of foreign dynasties basing their power on armies of steppe soldiers, although these Iranian soldiers had ceased to be part of the master narrative presented by the historians. Only a few individuals reached high leadership positions within the central army or government under Turco-Mongolian rule. The polities created by such people, for instance those of the the Kartids, Muzaffarids and the Sarbadarids, often retained autonomy for significant periods but sometimes had to accept Turco-Mongolian overlordship. Nonetheless Iranian regional elites continued to exist and to play a significant part, not only in local administration, but also in military affairs.

\section{$3 \quad$ Elites in the Timurid Period}

The early Timurid period - the reigns of Temür (r. 1370-1405) and particularly of his son Shāhrukh (r. 1409-1447) — was a time of unusually centralized control for Iran, in which a number of subordinate dynasties became more fully integrated into the state. Nonetheless, many smaller cities and regions remained under their own rulers for some time, and local military elites fought within Timurid provincial armies. Temür destroyed the regional powers strong enough to pose a potential threat: the Turco-Mongolian Jalayirids and the Iranian Kartids, Sarbadarids, and Muzaffarids. He also exiled the Iranian Mar'ashī

\footnotetext{
25 Smith, The History of the Sarbadār Dynasty, pp. 103-104, 115, 119, 122-123, 145; Melville, "Sarbadārids".

26 Shabānkāra'ī, Majma 'al-ansāb (this includes Faryūmadī's continuation), pp. 342-343.
} 
sayyids of Mazandaran. A number of the former servitors of these dynasties were then enrolled in his armies. Many rulers near the periphery of the realm submitted and retained their thrones: the rulers of Badakhshan, Sistan, Farah, Hormuz, Luristan, and much of the Caspian region continued as Timurid vassals. ${ }^{27}$ Of the smaller dynasties, many remained in place, though the sources give us only incidental information so we cannot gauge what proportion of the realm was fully incorporated. At the end of Ilkhanid rule we find the city of Qum under Iranian control, and the Timurid sources state that it remained under local rule through Temür's reign until it was taken by Temür's grandson Iskandar Sultān in $1414 / 1415{ }^{28}$ The nearby city of Sawa also appears to have remained under local rulership, as did the region of Tabas-i Gilak in Quhistan, where the family of the fortress keeper Amīr Shaykh 'Alī carved out a realm of respectable size along the trade route between Khurasan and Fars, lasting into the reign of Temür. ${ }^{29}$

Temür often confirmed the offices of local powers who submitted, and some of these are associated with quite small places. For instance we see Temür passing through the regional town (qașaba) Kusuya in Khurasan, and showing favor to Pahlawān Mahdī Kūsūyī who came out to greet him. ${ }^{30}$ Local rulers often hastened to show submission to a successful conqueror; a number could thus increase their holdings, as did for instance Sayyid Riḍā Kiyā of Gilan. ${ }^{31}$ It is likely that the numerous "local rulers" who came to offer submission to Temür on his arrival in their region included men at this level as well as the more prominent rulers like those of Shirwan and Gilan whose names appear in the histories. $^{32}$

A number of Iranian elites who submitted to Temür came fully into Temür's service and held quite important places, sometimes outside their own regions. Most notable among these are the amirs of Khurasan. The last ruler of the Sarbadars, Khwāja 'Alī Mu'ayyad Sabzawārī, surrendered the town to Temür and entered his armies, where he and his family served with some distinction. He was allowed to keep control of much of his former territory and, at his death in $788 / 1386-7$, his family and followers were granted important

27 Manz, The Rise and Rule of Tamerlane, pp. 90-94, 137, 156; Aubin, "Les princes d'Ormuz du XIII ${ }^{\mathrm{e}}$ au XV ${ }^{\mathrm{e}}$ siècle", pp. 111-119.

28 Drechsler, Die Geschichte der Stadt Qom im Mittelalter, pp. 23, 237; Manz, Power, Politics and Religion, p. 129.

29 Aubin,"La fin de l'état Sarbadâr du Khorasan", p. 98.

30 Fașịh, Mujmal, III, p. 116.

31 Shāmī, Zafarnāma, (Volume II contains additions made by Ḥāfiẓ-i Abrū.) II, p. 171.

32 See for example Shāmī, Zafarnāma, I, pp. 101, 294. 
regions in Khurasan: Bayhaq, Juwayn, Nishapur, and Faryumad. ${ }^{33}$ The family seems to have fallen out of favor early in Shāhrukh's reign; one member was executed, and many of their lands were confiscated. Later however some of the lands were returned, and a descendant known as Amīr Shāhī turns up as a prominent poet and landowner with connections to the Timurid dynasty. In the succession struggle after Shāhrukh's death a Sabzawārī is mentioned as fortress keeper. ${ }^{34}$

Another Khurasanian amir prominent in Temür's service was Jamshīd Qārin Ghūrī, who was appointed to Damghan and later made darugha (military governor) of Sari in Mazandaran, apparently with some Khurasanian troops under his command. On his death his son was appointed to succeed him. ${ }^{35}$ One of the fullest enumerations of Temür's commanders is the account of the long siege of Takrit in 796/1393; here we find a few Iranian commanders important enough to receive mention; they include one from Sawa and one from Qum. The conquest and incorporation of a region or town should not be seen as a sign that the local military elite were disenfranchised. The Timurids, like the Mongols before them, appointed military governors - darughas - to the cities and fortresses they controlled and sometimes also to vassal powers. These officials brought a small number of troops with them, usually in the low hundreds, thus not enough to control more than the city or town itself. While the appointment of a darugha signaled submission to the ruling power, the $d a-$ rughas might share power with local rulers or elites; thus their presence does not signal the extinction of regional commanders. ${ }^{36}$

The question before us is how to see below the ruling stratum of the Iranian leadership to the elite families who served them or the Timurids. As I suggested earlier, one solution is to look at regional histories, particularly those in the areas which retained relative independence and thus allow us to see into local politics. Just as the major dynastic histories present us with a history of the dynasty and its major servitors, so regional histories include the activities of people in the retinue of local rulers-men controlling towns or villages and leading modest military contingents. The historian Mar'ashi who recorded the history of Mazandaran and Gilan in the Timurid period presents a vivid picture of local politics. Comparing his account with that of the dynastic histories for the same incidents, we can see how much is left out of the central Timurid

33 Shāmī, Zafarnāma, I, p. 99, II, pp. 90, 118; Ḥāfiż-i Abrū, Cinq opuscules, p. 26.

34 Fașīh, Mujmal, III, p. 194, Dawlatshāh, Tadhkirat, pp. 426-427; Ṭihrānī, Diyārbakriyya, p. 323 .

35 Shāmī, Zafarnāma II, p. 66; Mar'ashī, Tārīkh-i Tabaristān, pp. 237-238, 244-246.

36 Manz, “The Office of Darugha under Tamerlane", pp. 59-61. 
chronicles. Mar'ashī's account of the politics of the Kār-Kiyā dynasty $(1367 / 8-$ 1592) of Lahijan and Ranikuh in Gilan for example shows constant political and military activity with the participation of neighboring dynasties related by marriage, numerous warring relatives, village headmen and fortress keepers, and local lords including the masters of Rasht, Lamsar and Kuhdum. ${ }^{37}$

In the provinces central to the Timurid state we can rarely see below the top level of Iranian leadership. One exception is the region of Qum, which as I have noted was under local control through Temür's reign. The story of the taking of Qum from its ruler Muhammad Qumī by Shāhrukh's nephew Iskandar Sulțān in 1412/1413 includes accounts of the actions of the keeper of a nearby fortress, a rebellious amir within the city, Muhammad Qumī's nephew and his retinue, and the ruler of Sawa. It is clear that this was a lively political field in which indigenous elites allied and fought each other. The success of the local leader depended heavily on the loyalty of the elites under him. In the event, Qum was taken with the help of one of Muhammad Qumïs servitors and a Timurid governor was installed, but we still find local amirs active in the city and region well after this. Sawa remained under its own ruler probably at least through Shāhrukh's reign, despite his brief defection to the Qaraqoyunlu. ${ }^{38}$ The city of Kashan was also part of this region, and there are some hints that its elites remained important in both the military and the political spheres. The city was taken for Shāhrukh in 818/1415-16, but shortly after this when one of the Timurid princes rebelled and took refuge with the Qaraqoyunlu tribal confederation of eastern Anatolia (1380-1468), Timurid rule appeared less secure and there were "disturbances" in several areas, including Kashan. ${ }^{39}$ During Shāhrukh's final illness, when his grandson Sulțān Muhammad was governor of the region of Qum, rulers of local regions began to turn to him and those of Kashan were among these. ${ }^{40}$ Thus it seems likely that despite its inclusion within the Timurid realm, Kashan still retained some level of autonomy under its traditional elites, who influenced decisions about what stand to take in times of contested leadership. Sawa, Qum, and Kashan together form a large region in the middle of the Timurid realm, and it is significant to find the continuation of regional elites in a powerful position here.

In the more fully incorporated regions, Iranians entered directly into Timurid service in military as well as civilian roles. Analysis of the Timurid histories indicates that the armies of the provinces played a significant part in campaigns,

37 Manz, Power, Politics and Religion, pp. 142-144.

38 Ḥăfiz-i Abru, Zubdat, pp. 481-483; Manz, Power, Politics and Religion, pp. 129-130.

39 Ḥāizz-i Abru, Zubdat, pp. 540, 591.

40 Manz, Power, Politics and Religion, pp. 252, 256. 
and that soldiers were recruited from the local Iranian population. Most were probably footmen, but there were some cavalry among them. We rarely hear of their commanders by name, but it is clear that many were Iranian, and seen as professionals. ${ }^{41}$ They seem to have included city populations and people of varied background beginning at a fairly low level and rising within the ranks. One example is two druggists from the bazar of Shiraz, who served in the army in Fars and rose to the status of commander, apparently through royal favor. ${ }^{42}$ In a number of cases we simply hear of regional armies with their commanders or of the sardārān (commanders) of a particular region, one or two of whom may be named. ${ }^{43}$ For instance the history of Shāhrukh's reign mentions sardārs of Qum and Kashan taking part in Shāhrukh's campaigns under the Chaghatay governor. ${ }^{44}$ There is some suggestion of an hereditary military elite: in one battle the history states that one tümen of the prince Iskandar's army was made up of sardārs or children of sardārs of Fars. These deserted in battle to join the ranks of the Isfahani opponents. ${ }^{45}$

Another soldier probably of urban origin who campaigned in the provincial army was the historian Tāj al-Dīn Hasan Yazdī, mentioned earlier for his discussion of his superior, Haāfiz al-Dīn Rāzì. His autobiographical information is of particular interest because it tells us of a career at a level which would otherwise not appear in the sources. Tāj al-Dīn began his military service as a tovachi of a unit of ten men in the army of Yazd; at this time he was about twentyfour. He gives a vivid description of the army's campaign near Hamadan in the succession struggle after Temür's death, in which his regiment first won and then lost an astounding amount of booty. ${ }^{46}$ Somewhat later we find him campaigning in Kerman, still tovachi, now in the army of Yazd and Abarquh, which included a corps of 450 missile throwers. ${ }^{47}$ Later he served the governor of Kerman in bureaucratic and religious offices, supervising the ashräf khāna-i khāsșa, zakat, and the camp market. He states that for thirty years he managed the waqfs of Kerman..$^{48}$ At the top level, the command of regional armies was determined by the governor or the ruler and sometimes given to viziers; one of

\footnotetext{
41 Manz, Rise and Rule of Tamerlane, pp. 96-100; idem, Power, Politics and Religion, pp. 123-126.

42 Manz, Power, Politics and Religion, p. 126.

43 See for example: Fașịh, Mujmal, III, p. 226; Ṭihrānī, Diyārbakriyya, p. 350.

44 Ḥāfiż-i Abrū, Zubdat, p. 720.

45 Hafiz-i Abrū, Zubdat, p. 347.

46 Yazdī, Hasanī, pp. 14, 30-32, 42.

47 Manz, Power, Politics and Religion, pp. 53, 124.

48 Yazdī, Hasanī, pp. 15, 48, 93.
} 
Temür's viziers was appointed commander of the "Tajik forces", and the vizier Ḥāfiz Rāzī, mentioned above, commanded a tümen of the army of Fars. ${ }^{49}$

Looking at Iranian elites under the Timurids then, we can see a spectrum of independence and activity, from local rulers acting as vassals and joining Timurid campaigns leading their own troops, to Iranian commanders serving the Timurids directly and commanded by officers appointed from above. In the middle there is a shadowy group of men controlling small territories, whose status is hard to determine. We really cannot tell what level of autonomy was enjoyed by the rulers of Kusuya, Sawa and Qum. For all of these people however, the level of power and independence they enjoyed depended on shifting circumstances. Over the early Timurid period, as with earlier times, we see the pendulum swinging back and forth between centralization and local control. During the disturbances after Shāhrukh's death, vividly described by the historian Tịhrānī, Iranian military elites again emerge as significant actors, mentioned by name. ${ }^{50}$ In periods of regional struggle members of the Iranian elite appear as independent rulers over a variety of realms, some ruling important cities and large portions of a province, others a few hundred square kilometers with a few towns. With the reassertion of central power, some rulers submit while some resist and are removed, but the underlying stratum of military actors remains in place, sometimes serving the higher power, sometimes pursuing local rivalries. When central control weakens, they will reemerge in the pages of the histories.

\section{The Nature of the Iranian Provincial Elite}

In the first part of this chapter I have attempted to illuminate the role of the Iranian elite in the military sphere, to counteract the silence of our sources. A question I want to pose now is how separate and different Iranian military families were from the religious and bureaucratic lineages more fully described in the biographical literature. The literature about professional groups stresses doctrinal and familial relationships, sometimes allowing us to follow several generations. As I stated above, biographies give us the impression of relatively closed professions, with families in which a given specialization passed down from one generation to the next. They also naturally focus on the most prominent figures, usually those active in the larger cities, and it is the life of these cities which has shaped our understanding of both the elite and the professions

49 Manz, Power, Politics and Religion, pp. 106-107, 124.

5o Țihrānī, Diyārbakriyya, pp. 295, 350, 323, 326, 332, 343. 
they followed. However, a number of the families who produced bureaucratic and religious professionals were centered in smaller cities and more rural regions. Here I will attempt to follow them back into the countryside.

When we go outside the major cities and try to pass from the lives of individuals to those of families, we face additional challenges from the silences of our sources. One solution, again, is to turn to the biographies of historians. Two historians from the Mongol period provide examples of families in which combinations of military and civilian activity were traditional. One is the historian Shihāb al-Dīn Muḥammad al-Nasawī (d. 1249/50), who served under the Khwarazmshāhs at the time of the Mongol invasion. His family held a fortress and surrounding villages near Nasa in Khurasan as freehold, which he claimed had belonged to his family from the beginning of Islamic rule in Khurasan. He was trained in both military and bureaucratic affairs, achieving mastery of Arabic as well as Persian and expertise in chancellery practice. It appears that his family had a tradition of administrative service to the Khwarazmshāhs, and probably to earlier dynasties as well. ${ }^{51}$

Another historian of the Mongol conquest was Qāḍi Minhāj al-Dīn b. Sirāj al-Dīn Jūzjānī (d. probably after 1265), active first in Ghur and then in India in the service of the Delhi sultanate (1206-1555). His father's family stemmed from Juzjan in northern Khurasan and was noted for its learning. On his mother's side he was connected to the Ghurid dynasty. Members of both families held the office of $q \bar{a} a \underline{d}$. In Jūzjānī's paternal line, the only person whose career we know about was his father, who was $q \bar{a}$ di both in the army and in Bamiyan where he also served as muhtasib (religious inspector of market practice and public morality) and supervisor of two madrasas. He is mentioned acting as an envoy but never in a military role..$^{52}$ On Jūzjānī's maternal side, we have more information and find a mix of religious and military activity. Two relatives receive mention. One, Diyā̄a al-Dīn Muhạmmad b. 'Abd al-Salām Tūlakī, apparently a first cousin of the author's grandfather, was put in charge of the fortress Tabarhinda on its conquest by the Ghurid ruler in about 1191-2; both the cousin and the author's grandfather are identified as $q \bar{a} d \bar{l}$ s. Once appointed to Tabarhinda Ḍiyā' al-Dīn quickly requested that 1200 horsemen from Hindustan and Ghazna be sent to him to attach to his regiment. Later he was put in charge of Junabad. ${ }^{53}$ About thirty years later in $1220-2$ when the town of Tulak, closely connected to Minhāj's family, was given up to one of the Ghurid rulers,another relative, Qāḍī Jalāl al-Dīn Majd al-Mulk, was installed as governor

51 Paul, "Dihqāns", pp. 23-26.

$5^{2}$ Bosworth, "Menhāj”; Moin, "Qāḍī-Minhāj Sirāj al-Juzjānī”.

53 Jūzjānī, Tabaqāt, trans. Raverty, pp. 381, 457-458; ed. Ḥabībī, I, pp. 397-398. 
(hâkkim) ${ }^{54}$ The author was himself a $q \bar{a} d \bar{\imath}$ and was appointed to several religious offices during his long service in India, primarily as qādī but also as principal of a madrasa. In his early years he was active also militarily; in 1222-3 he helped to defend Tulak against the Mongols, and for four years after that joined with members of other major families in Tulak to fight the invaders. He mentions that the people of Tulak were all kinsmen and brothers. ${ }^{55}$ What we have here then is someone coming from two families with a tradition of religious training, one of which also played a military role over several generations; either one or both families married into a regional elite which was militarily active.

We can find several people who appear to come from provincial families of mixed profession serving in the dīwān in the Timurid period. One is the family of Sayyid Zayn al-Ābidīn Junābādī, active in the dīwān under both Temür and Shāhrukh. Sayyid Zayn al-Dīn was a landowner in Junabad, a large town in Quhistan, who had at least some training in the religious sciences. His son likewise served in the dīwān and was also known for his learning in both exoteric and esoteric sciences. ${ }^{56}$ While the Junābādī family combined bureaucratic and religious activity, that of Jalāl Islām was involved in military and bureaucratic affairs. Jalāl Islām came from a regional family in Tabas Masinan, in Quhistan, which clearly had local military power. His brother served as fortress keeper and governor. ${ }^{57}$ Jalāl himself served as a vizier in Temür's dīwān until he was slandered and dismissed from the dīwān. He was subsequently put in charge of the Tajik forces in the army. The historian and bureaucrat Isfizārī (d. 1510), writing in the later Timurid period, mentions a member of Jalāl Islām's family as an acquaintance; he is given the title amirr, and presented as a cultured person, sending a $r u b \bar{a} c \hat{\imath}$ (a quatrain of poetry) to the author, who answered in kind. ${ }^{58}$

Under the Timurids two regions provided an exceptionally large number of bureaucrats to the dīwann; these were Simnan and Khwaf. Both seem to have

54 Jūzjānī, Ṭabaqāt, trans. Raverty, p. 106o; ed. Ḥabībī, II, pp. 134-135. The passages concerning the author's maternal relatives are confusing, particularly the second one. Raverty decided that the two relatives mentioned in these two incidents were probably one person, and that the word "grandfather" in the first passage should be considered an interpolation. However, since the names and nasabs of the two men are different and the events described are thirty years apart, I suggest that these are probably different men; the relationship of the second however is not the same in all manuscripts, and in one variant, his position is hăkim of Nishapur; what is clear is that he was a relative, and that he held the position of city governor.

55 Bosworth, “Menhāj”; Jūzjānī, Țabaqāt, trans. Raverty, p. 1061.

56 Manz, Power, Politics and Religion, p. 107.

57 Manz, Power, Politics and Religion, pp. 106-107.

$5^{8}$ Isfizārī, Raw d̦āt al-jannāt, I, p. 114. 
had a tradition of military, religious and bureaucratic professions. It is significant that the notable figures stemming from these regions did not abandon local attachments when they left to pursue a career elsewhere. Many used the money from their positions to endow institutions and public works in their native regions. It is perhaps for this reason that the areas continued as training grounds for various professions, most notably but not exclusively, the dīwān. In Simnan the combination of professions dated at least from the Mongol period, when we find Simnānīs as religious figures, bureaucrats and military men. In his collection of dīwān biographies, the Dastūr al-wuzarā', the historian Khwāndamīr (d. 1539/40) writes that the region of Simnan had two prominent extended families (qabïla): the Bālīcha and the Bahrāmī. The Bahrāmī traced its descent from Bahrām Gūr, in classic Iranian fashion. These two families stood out among the rest for their aristocratic lineage; they commanded obedience and gave refuge to the population. There is no explicit mention of military activity here, though the mention of obedience and protection suggest some level of military or paramilitary force. Two Simnānī viziers of the Timurid period were active militarily. One of the prominent Simnānī viziers who served under Temür and Shāhrukh died in battle, and Malik Ḥusayn Simnānī, almost certainly a member of the Bālīcha, served in the dìwān in Herat, then moved to the dīwān in Fars, where he led troops on important expeditions, and is mentioned as part of the council of great amirs..$^{59}$

We are particularly well informed about the region of Khwaf in Quhistan, which produced a large number of men prominent in Khurasan, some of them historians. I have already discussed the family of the historian Fașịh Khwāfĩ, active in the Herat dīwān. Here the family progenitor, Majd al-Dīn Muhammad, was a military figure with regional power whose son came into the service of the Kartid rulers of Herat. Fașị himself and the two contemporary relatives he mentions seem to have been active in the diw $\bar{a} n{ }^{60}$ In the later Timurid period especially, we find members of the family active in both the bureaucracy and in the religious sciences. ${ }^{61}$ Among those working in the diw $\bar{a} n$ in the later period was the vizier Qiwām al-Dīn Nizāàm al-Mulk Khwāfî, patron of the historian Isfizārī, who gives him lavish praise and lists his many illustrious ancestors and relatives. The list of families named among his progenitors gives us an excellent illustration of what was considered prestigious, and of the variety of elite intermarriages. Like Fașịh Khwāfì, Qiwām al-Dīn came from Khwaf and was descended from Majd al-Dīn Muhammad Māyizhnābādī. He also claimed

\footnotetext{
59 Khwāndamīr, Dastūr, pp. 380-381; Manz Power, Politics and Religion, pp. 101-103.

6o Manz, Power, Politics and Religion, pp. 96-98.

61 Manz, Power, Politics and Religion, p. 99.
} 
descent from the Sufi Hiidrat Shāh Sanjān, whose family and shrine are highlighted in Fașịh Khwāfi's work. Two more major figures of the Khwaf region appear as ancestors: Malik-i Zūzan, who ruled in the region just before the Mongol invasion, and Qādī Shams al-Dīn Muhammad of Zuzan, prominent in the Mongol period. ${ }^{62}$ The Sufi shaykh Aḥmad-i Jām, known as Zhinda Pīl, also counts among Qiwām al-Dīn's ancestors; this connects him to the Shaykhs of Jam, also centered in Quhistan. Other ancestors are the amirs of Raza, near Bakharz, powerful in the Kartid period. ${ }^{63}$ In addition to incidental mentions of relations, Isfizārī gives a list of Qiwām al-Dīn's ancestors by category, which goes further afield and further back, and may well be embellished. Here there are sayyids, great Sufi shaykhs, kings (of Badakhshan and Sistan), pillars of state including the Barmakids, and the great viziers of Sanjan and Mathirnabad. ${ }^{64}$

Leaving out stock figures such as the Barmakids, we find that most of the families mentioned are of local provenance, many of them from Quhistan not far from Khwaf. What we have is a picture of intermarriage among families of regional prominence in a number of professions, from local rulers and amirs to 'ulama' and Sufis. For any ambitious man, such connections would offer a broad range of careers and connections among which to choose.

As I have shown there is evidence of elite Iranian families and individuals prominent in several professions, and of the presence of provincial armies in which Iranian personnel made up a significant part of recruits and command. When we allow for the bias of the sources, we should conclude that the examples we know of are a small proportion of those that existed. Therefore, it seems likely that many elite landholding families in Iran were trained and active in more than one sphere and served their rulers in more than one capacity. If we accept this, we should change our view of Iranian society and government in several ways. For one thing we need to consider the likelihood that the difference between the Iranian and the Turco-Mongolian elites was not quite as stark as it has been portrayed and that Iranians were not without a living martial tradition. This conclusion leads to the question of military education.

62 Isfizārī, Rawụ̂āt al-jannāt, I, pp.200-201, 215.

63 Isfizārī, Raw ḍāt al-jannāt, I, pp. 217, 231.

64 Isfizārī, Rawḍāt al-jannāt, I, pp. 216-217. 
Historians have long noted that Iranian viziers sometimes led troops in battle. That makes sense. Since at least part of the diw ān accompanied the ruler on campaign, it was common for viziers to be present in the army camp. Presence does not in itself indicate an active military role, and for the Timurid period at least, the level of actual military activity of the viziers seems to have varied considerably. The historian Abū Bakr Țihrānī Isfahānī (d. after 1481/2), active in the later Timurid period, gives us some details of his career; he states that he drafted several important documents and portrays himself as serving as mediator and influencing the council of amirs, but gives no indication that he participated in battle. ${ }^{65}$ For most viziers we have no information about military command.

It is clear however that a number of viziers were active in battle and some appointed to significant command; three, Jalāl Islām, Malik Ḥusayn Simnānī, and Ḥāfiz Rāzì, have been discussed above. Jalāl Islām, having been denounced for irregularities in the dīwann, was then appointed to lead the Tajik armies. It is interesting to find a similar incident later, when Sulțān Abū Sa'ìd, acting on denunciations, dismissed his favored vizier, Khwāja Shams al-Dīn Muḥammad b. Sayyidi Ahmmad Shīrāzī, then later recalled him and sent him to take Isfahan from Jahānshāh Qaraqoyunlu, which he did successfully. ${ }^{66}$ The important commands held by these and some other viziers required significant military skills. The size of the commands that these men held suggest that they were mounted and probably trained also in mounted archery, a difficult art. They also had to know enough about combat to manage troops. The expertise required for such activity could not be acquired quickly and probably did not come only after they had been appointed to office. It seems likely that the viziers appointed to such commands were those who were known to have significant training and experience already, probably from their youth.

While the military role of some viziers is well known, there has been less discussion of such activity on the part of the 'ulama', and particularly of the $q \bar{a}$ ḍī. However, the military activity of the Simnānī $q \bar{a} d \grave{l} \bar{s}$ and those of Jūzjānī's family is not a phenomenon limited to the Mongol period. As I indicated earlier, it is clear that in many, perhaps in most cities, while the defense of the citadel was the task of the garrison forces commanded by the darugha or the governor, the walls and gates of the rest of the city were defended by the population, usually under the command of the $q \bar{a} d \bar{q} .{ }^{67}$ In some cases the $q \bar{a} d \bar{\imath}$ and civilian population operated under the supervision of the governor, but this was not

65 Ṭihrānī, Diyārbakriyya, pp. vII-XV, 290-293, 325, 343-346.

66 Khwāndamīr, Dastūr, pp. 367-369.

67 See footnote 4 above. 
always the case. It is useful to remember that sieges of the major cities were not an uncommon occurrence; the death of many, perhaps most, rulers ushered in a period of struggle lasting often several years. During this period major cities faced successive armies and needed to decide whether or not to submit, and, if they did not submit, had to organize a defense. It appears then that the defense of the city was a part of the chief $q \bar{a} d \vec{\imath} \grave{s}$ duties, and it was something he could expect to do during the course of his career. The defense of a large city was a complex operation, requiring an understanding of the city's fortifications and also of the tactics and equipment of the army standing outside. It seems unlikely that this task would be entrusted to someone whose only qualification was religious and social authority.

If military activity was part of the lives of many qā what sort of training it required and when that would have been received. We know that archery was an art practiced by some of the Iranian population and was part of the futuwwa discipline that may well have been central to the defenders of cities. We should not be surprised then when we find two people with the title Mawlānā, suggesting religious learning, mentioned as crucial defenders of the Samarqand in a time of siege; we also find a mawlānā named elsewhere as a fortress keeper. ${ }^{68}$ While the skills needed to defend the city from within may have been limited to archery and paramilitary skills, it was not infrequent for city troops to make forays outside the city against the besieging army. We see this happening for instance in Isfahan, at the beginning of Shāhrukh's reign, under the leadership of Qāḍī Aḥmad Șācidī. ${ }^{69}$ If city troops were competent to engage an army of Turco-Mongolian troops, they must have been at least partially mounted and certainly competently led. Here again, long-term military training seems likely and would probably have begun early, within the circle of the family.

As with viziers, it is probable that $q \bar{a} d \bar{\imath} s$ and city populations varied in military expertise. Qâdị Aḥmad Ṣāiidī belonged to a family which had long held the judgeship of Isfahan, and had held Isfahan and its region as an autonomous realm for some time during the late Seljukid period..$^{70}$ The qā mother's family also stood out for military activity. Some cities sent troops out to fight in the field, while others defended exclusively from within. We should recognize that a proportion of both 'ulama' and bureaucrats probably had significant military training, and used it as a part of their professional duties.

68 Manz, "Nomad and Settled", p. 441; Țihrānī, Diyārbakriyya, p. 323.

69 Manz, "Nomad and Settled", pp. 443-444.

70 Durand-Guédy, Iranian Elites, pp. 230-242, 281-297. 
A second conclusion to draw from the material presented above is that we need to look beyond the major cities in delineating the relationship between state and society. At the higher levels of administration, the dynastic and provincial capitals were undoubtedly the most prominent interface. In smaller cities and the countryside likewise Iranians elites were more than civilian subjects or mediators between a local client population and a foreign government.

Scholars have usually seen the important role of local actors in the context of the limited reach of the central government Certainly it is clear that in times of disorder at the center, local elites were quick to take advantage and carve out autonomous spheres. However, this was not their only importance in the political arena. It is possible to look at the situation also in a different light. Where government could not fully control local populations, it still could bring elites into its sphere by offering advantages to connection with a higher power. Provincial landowning families lived in a competitive world and could profit from government service in different ways. They might serve in provincial armies, gaining booty, strengthening their retinues, and thus enhancing also their local power. Service in either provincial or central dīwāns could also bring wealth which translated into greater local power. In Khwaf and Simnan government officials sometimes invested their new wealth in their home regions, strengthening both the local society and their position within it. A family could continue to prosper through turns of fortune by adjusting the professions of its members and by marrying into families with other useful skills or connections.

We should not see the Iranian elite as civilians defenseless against the depredations of the government and its armies; many were part both of that government and of those armies. The darughas stationed with a small number of troops in towns, forts and villages were often acting in concert with local power holders, in both the military and the civilian spheres. Thus despite their foreign origin, the Timurids and other Turco-Mongolian dynasties were probably not a distant and alien presence for many of their subjects. The Iranian elite were not equal to their Turco-Mongolian rulers, but they were politically active and connected to the central state at many different levels and venues, from the chancellery to the army, and from provincial capitals to townships and mountain fortresses.

\section{Bibliography}

\section{Primary Sources}

Mu izz al-ansāb fì shajarat al-ansāb, MS Paris, Bibliothèque Nationale, \#67.

Bāfqī, Muḥammad Mufìd Mustawfì, Jāmí-i mufìd̄i, İraj Afshār, ed., 3 vols. (Tehran, 1340). 
Dawlatshāh Samarqandī, The Tadhkiratu 'sh-shu'arā ("Memoirs of the Poets"), E.G. Browne, ed. (London, 1901).

Fașịh Khwāfî, Aḥmad b. Jalāl al-Dīn, Mujmal-i Faṣị̣ī, Muḥammad Farrukh, ed. (Mashhad, 1960/1961).

Ḥāfiz-i Abrū, Cinq opuscules de Hā̃fiz-i Abrū concernant l'histoire de l'Iran au temps de Tamerlan, F. Tauer, ed. (Prague, 1959).

Ḥāfiz-i Abrū, Zubdat al-tawārīkh, Sayyid Kamāl Ḥājj Sayyid Jawādī, ed. (Tehran, sh. 1372/1993-4).

Isfizārī, Mu'īn al-Dīn Zamchī, Raw dāt al-jannāt fì awșāf madīnat Harāt, Sayyid Muḥammad Kāzim Imām, ed. (Tehran, sh. 1338/1959).

Ja'farī, Ja'far b. Muhammad al-Ḥusaynī, Tārīkh-i kabīr, MS St. Peterburg, Publichnaia Biblioteka im Saltykova-Shchedrina, PNC 201.

Ja'farī, Ja'far b. Muḥammad al-Ḥusaynī, Tārīkh-i Yazd, Īraj Afshār, ed. (Tehran, 1338/1960).

Jāmī, 'Abd al-Raḥmān, Nafaḥāt al-uns min ḥị̂rāt al-quds, Mahdī Tawḥīdīpūr, ed. (Tehran, sh. 1375/1996-1997).

Jūzjānī, Minhāj Sirāj, Ṭabaḳāt-i Nāṣirì: A General History of the Muhammadan Dynasties of Asia, Including Hindustan, from A.H. 194 (810 A.D.) to A.H. 658 (1260 A.D.) and the Irruption of the Infidel Mughals into Islam, Henri G. Raverty, trans., 3 vols. (London, 1881-97) (Reprint New Delhi, 1970).

Jūzjānī, Minhāj Sirāj, Ṭabaqāt-i Nāṣirī, 'Abd al-Ḥayy Ḥabībī, ed. (Kabul, 1964).

Kātib, Aḥmad b.Ḥusayn b. 'Alī, Tārīkh-ijadīd-iYazd, ed.ĪrajAfshār(Tehran,1345sh./1966).

Khwāndamīr, Ghiyāth al-Dīn b. Humām al-Dīn, Dastūr al-wuzarā', Sa'̄id Nafīsī, ed. (Tehran, sh. 1317/1938-39).

Mar'ashī, Sayyid Zahīr al-Dīn b. Nașīr al-Dīn, Tārīkh-i Tabaristān wa Rūyān wa Māzandarān, Muhammad Ḥusayn Tasbīḥī, ed. (Tehran, 1966).

Nasawī, Muḥammad b. Aḥmad, Sìrat as-Sulțān Dzhalāl ad-Dīn Mankburny: Zhizneopisanie Sultana Dzhalal ad-Dina Mankburny, Ziya M. Buniyatov, trans. (Pamyatniki pis'mennosti Vostoka 107) (Moscow, 1996).

Navāī', Mīr 'Alī Shīr, Majālis al-nafā’is dar tadhkirai-ii shu'arā'-i qarn-i nuhum-i hijrī, ta'līf-i Mōr-i Niz̄ām 'Alī Shīr Nawā̄i, 'Alī Asghar Hikmat, ed. (Tehran, sh. 1323/1945).

Shabānkāra'ī, Muḥammad b. 'Alī b. Muḥammad, Majma' al-ansāb, M.H. Muhạaddith, ed. (Tehran, 1985/1986).

Shāmī, Nizāām al-Dīn, Histoire des conquêtes de Tamerlan intitulée Zafarnāma, par Nizāmuddīn Šāmī, F. Tauer, ed. (Prague, vol. I, 1937, vol. II, 1956).

Ṭihrānī Iṣfahānī, Abū Bakr, Kitāb-i Diyārbakriyya, N. Lugal and F. Sümer, eds. (Ankara, 1962-1964).

'Uqaylī, Sayf al-Dīn Ḥājjī b. Niẓām, Āthār al-wuzarā', Mīr Jalāl al-Dīn Ḥusaynī Armawī, ed. (Tehran, sh. 1337/1959-1960).

Yazdī, Sharaf al-Dīn 'Alī, Zafarnāma, Muḥammad 'Abbāsī, ed. (Tehran, sh. 1336/1957). 
Yazdī, Tāj al-Dīn Ḥasan b. Shihāb, Jāmic al-tawārīkh-i Hasanī, Husayn Mudarrisī Ṭabāṭabā'ī and Īrāj Afshār, eds. (Karachi, 1987).

\section{Secondary Sources}

Aigle, Denise, Le Fārs sous la domination mongole. Politique et fiscalité (XIII $\left.I^{e} X I V^{e} s.\right)$ (Cahiers de Studia Iranica 31) (Paris, 2005).

Amitai, Reuven, "Armies and their economic basis in Iran and the surrounding lands, c. 1000-1500 C.E", in David O. Morgan and Anthony Reid, eds., New Cambridge History of Islam, vol 3: The Eastern Islamic World, Eleventh to Eighteenth Centuries (Cambridge, 2010), pp. 539-560.

Aubin, Jean, "Les princes d'Ormuz du XIII e au XVe siècle", Journal Asiatique 241 (1953): 77-137.

Aubin, Jean, ed., Matériaux pour la biographie de Shah Ni'matullah Wali Kermani (Tehran, Paris, 1956).

Aubin, Jean, "La fin de l'état Sarbadâr du Khorasan", Journal Asiatique 262 (1974): 95-117.

Aubin, Jean, “Le Khanat de Čagatai et le Khorasan (1334-1380)", Turcica 8/2 (1976): 16-6o.

Bosworth, Clifford E., "Menhāj-e Serāj”, Encyclopaedia Iranica.

Cahen, Claude, Mouvements populaires et autonomisme urbain dans l'Asie musulmane du moyen age (Leiden, 1959).

Drechsler, Andreas, Die Geschichte der Stadt Qom im Mittelalter (650-1350): politische und wirtschftliche Aspekte (Berlin, 1999).

Durand-Guédy, David, "Iranians at War under Turkish Domination: The Example of Pre-Mongol Isfahan", Iranian Studies 38/4 (2005): 587-6o6.

Durand-Guédy, David, Iranian Elites and Turkish Rulers: A history of Isfahān in the Saljūq period (London, 2010).

Garthwaite, Gene R., The Persians (Oxford, 2005).

Jackson, Peter, The Delhi Sultanate: A Political and Military History (Cambridge, 1999).

Manz, Beatrice F., "The Office of Darugha under Tamerlane", in Joseph Fletcher, Richard N. Frye, Yuan-chu Lam, and Omeljan Pritsak, eds., An Anniversary Volume in Honor of Francis Woodman Cleaves, Journal of Turkish Studies 9 (1985): 59-69.

Manz, Beatrice F., The Rise and Rule of Tamerlane (Cambridge: Cambridge University Press, 1999).

Manz, Beatrice F., "Nomad and Settled in the Timurid Military", in R. Amitai and M. Biran, eds., Mongols, Turks and Others: Eurasian Nomads and the Sedentary World (Leiden, 2005), pp. 425-457.

Manz, Beatrice F., "Local Histories of Southern Iran”, in J. Pfeiffer and Sh. A. Quinn, eds., History and Historiography of Post-Mongol Central Asia and the Middle East: Studies in Honor of John E. Woods (Wiesbaden, 2006), pp. 267-281. 
Manz, Beatrice F., Power, Politics and Religion in Timurid Iran (Cambridge: Cambridge University Press, 2007).

Manz, Beatrice F., "Nomads and Regional Armies in the Middle East", in Kurt Franz and Wolfgang Holzwarth, eds., Nomad Military Power in Iran and Adjacent Areas in the Islamic Period (Wiesbaden, 2015), pp. 1-27.

Melville, Charles, "Sarbadārids", $E I^{2}$ (<http://dx.doi.org/10.1163/1573-3912_islam_SIM -6630>).

Moin, Mumtaz, "Qāḍī-Minhāj Sirāj al-Jūzjānī",Journal of the Pakistan Historical Society 15/3 (1967): 162-174.

Paul, Jürgen, The State and the Military: the Samanid case (Bloomington, 1994).

Paul, Jürgen, Herrscher, Gemeinwesen, Vermittler: Ostiran und Transoxanien in vormongolischer Zeit (Beiruter Texte und Studien 59) (Beirut, 1996).

Paul, Jürgen, "L'invasion mongole comme 'révélateur' de la societé iranienne", in D. Aigle, ed., l'Iran face à la domination mongole (Bibliothèque Iranienne 45) (Tehran, 1997), pp. 37-53.

Paul, Jürgen, "Wehrhafte Städter: Belagerungen von Herat, 1448-1468”, Asiatische Studien/Études Asiatiques 58/1 (2004): 163-193.

Paul, Jürgen, "Where did the dihqāns go?", Eurasian Studies 11 (2013): 1-34.

Paul, Jürgen, Lokale und imperiale Herrschaft im Iran des 12. Jahrhunderts: Herrschaftspraxis und Konzepte (Wiesbaden, 2016).

Potter, Lawrence G., "The Kart Dynasty of Herat: Religion and Politics in Medieval Iran" (Ph.D. dissertation, Columbia University, 1992).

Smith, John Masson, The History of the Sarbadār Dynasty 1336-1381 A.D. and its Sources (The Hague, 1970). 